MirosŁawa Ampel-Rudolf

Uniwersytet Rzeszowski

Centrum Kultury i Języka Polskiego

dla Polaków z Zagranicy i Cudzoziemców „Polonus”

\title{
Kategoria rodzaju gramatycznego i semantyczna kategoria istotności poznawczej (żywotności)
}

Słowa klucze: rodzaj gramatyczny, kategoria istotności poznawczej, dystynkcje, opozycje, model M. Silversteina

W najnowszych pracach lingwistycznych naukowcy wykraczają daleko poza sferę tradycyjnego zakresu badań językowych, a gramatyka z jednego z najważniejszych przedmiotów badawczych staje się we współczesnych analizach tylko elementem współtworzącym wraz z innymi elementami proces komunikacji. Problemy gramatyczne są obecnie rozpatrywane w szerszej perspektywie i w różnych aspektach, np. pragmatycznym, ideologicznym. Jednak nadal niektóre z nich nie doczekały się takiego opracowania systemowego, które byłoby akceptowane przez większość i nie budziło dużych kontrowersji. Kategoria rodzaju rzeczownika jest tego przykładem.

1. Przedmiotem rozważań w moim artykule są kategoria rodzaju gramatycznego i semantyczna kategoria żywotności, dla której przyjmuję określenie kategorii istotności poznawczej ${ }^{1}$.

1 Jako kategorię traktuje problem męskożywotności i męskoosobowości rzeczowników np. J. Mindak (1991). 
1.1. Kategoria rodzaju rzeczownika, zarówno w sensie węższym - podział na rodzaj: męski, żeński, nijaki, jak i szerszym - z uwzględnieniem w obrębie rodzaju męskiego w języku polskim problemu żywotności i osobowości, była i jest przedmiotem nieustająco wznawianych dyskusji i rozważań. Pojawiają się sformułowania, że jest to kategoria złożona, wielopoziomowa, wieloaspektowa. Z. Zaron uważa, że dopiero charakterystyka fleksyjna, semantyczna i pragmatyczna leksemu pozwala na wyznaczenie reguł selekcji form rodzajowych w większych kontekstach składniowych (Zaron 2004: 100).

$\mathrm{Z}$ obszernej literatury poświęconej zagadnieniom rodzaju w języku polskim obecnie najczęściej przywoływane są prace Mańczaka, Kucały, Saloniego, Laskowskiego (Mańczak 1956; Kucała 1971, 1976; Saloni 1976; Laskowski 1984; popr. 1999). Najnowszym, obejmującym analizę prawie wszystkich rzeczowników współczesnego języka polskiego (wszystkie jednostki jednowyrazowe oprócz nazw własnych), jest rozprawa Zofii Zaron. Autorka zamieszcza też wyjatkowo bogatą bibliografię przedmiotu (Zaron 2004).

1.2. Kategoria żywotności - sygnalizowana w języku polskim w rzeczownikach w rodzaju męskim przez opozycje: w 1.p. żywotne/nieżywotne, w 1.m. osobowe/nieosobowe, w pracach polskich językoznawców rzadko bywa omawiana odrębnie, poza kategorią rodzaju. Do tych nielicznych badaczy należy Jolanta Mindak, która analizowała jej funkcjonowanie w językach słowiańskich, i Zuzanna Topolińska - która wykorzystała ją w swojej najnowszej interpretacji kategorii przypadka (Mindak 1990, 1991; Topolińska 1996).

2. W badaniach nad kategorią rodzaju w nauce polskiej w kolejnych okresach dominowały różne stanowiska. Tradycyjnie wyróżniano trzy wartości rodzaju rzeczownika: męski, żeński i nijaki. Obecnie w analizach językoznawczych preferowana jest klasyfikacja, w której wyróżnia się trzy klasy w obrębie rodzaju męskiego - osobowe, żywotne nieosobowe, nieżywotne (rzeczowe) oraz rodzaj żeński i nijaki². Wprowadzona została przez Mańczaka, stosowana przez Kucałę, a wykorzystana m.in. w opisie kategorii rodzaju w „Gramatyce współczesnego języka polskiego" przez Romana Laskowskiego. Każdy z badaczy, przyjmując wprawdzie inną podstawę metodologiczną i stosując odmienne procedury,

2 W praktyce szkolnej w liczbie pojedynczej wyróżnia się dla rzeczownika rodzaj męski, żeński i nijaki, w licznie mnogiej męskoosobowy i niemęskoosobowy. 
a także terminologię, wyodrębnia dla rzeczownika następujące wartości kategorii rodzaju: męskoosobowy, męskożywotny, męskonieżywotny, żeński i nijaki³ .

Zofia Zaron w swojej pracy uzasadniła, że możliwe jest wyodrębnienie klas rodzajowych wyłącznie na podstawie kryteriów fleksyjnych. Zaproponowała zastosowanie określonych zhierarchizowanych dystynkcji, jednakowych dla obu liczb, na kilku poziomach analizy: końcówek dopełniacza, mianownika oraz synkretyzmów biernika. W efekcie otrzymała również pięć klas rodzajowych (ostatnia z dwiema podklasami): żeńska niemęskoosobowa, męska żywotna, męska nieżywotna, nijaka, męskoosobowa i tu - żeńska męskoosobowa i męska męskoosobowa (Zaron 2004: 94).

Jednym słowem, współcześnie przyjmuje się, że termin „rodzaj” obejmuje zarówno tradycyjne rozróżnienie na rodzaj gramatyczny (rozumiany jako opozycja do rodzaju motywowanego semantycznie - naturalnego), jak i klasyfikację rzeczowników, której podstawą są semantyczne opozycje: żywotny/nieżywotny i osobowy/nieosobowy. Te ostatnie w gramatyce języka polskiego sąjednak różnicujące tylko dla klasy rzeczowników rodzaju męskiego ${ }^{4}$.

Wbrew panującej od dłuższego czasu zgodzie na takie ujmowanie kategorii rodzaju wśród polskich językoznawców, chciałabym wykazać, że między kategorią rodzaju gramatycznego i kategorią istotności poznawczej występują znaczne różnice.

3.1. Rodzaj to kategoria, która w języku polskim przysługuje odmiennym częściom mowy: rzeczownikom, przymiotnikom, większości zaimków, części liczebników oraz formom czasowników opartym na imiesłowie przeszłym czynnym, a także imiesłowom przymiotnikowym. W związku z zasadniczą różnicą między aspektami kategorii rodzaju rzeczownika a pozostałych części mowy, przedmiot analizy zostanie ograniczony do rzeczownika ${ }^{5}$.

3 Z. Saloni i H. Wróbel wyróżniają jeszcze dwie klasy rodzajowe; osobowe i nieosobowe - dla grupy rzeczowników plurale tantum (Saloni 1976: 179, Wróbel 2001: 91).

4 Z. Saloni i Z. Zaron po części wyjaśniają podstawę łączenia tych dwóch różnych zjawisk „Etykietka 'męskoosobowe' odnosi się wyłącznie do charakterystyki gramatycznej” (Zaron 2004: 31).

5 Kategoria rodzaju dla pozostałych odmiennych części mowy, innych niż rzeczownik, jest kategorią syntaktycznie zależną, niedeterminującą i fleksyjną. Kategorię rodzaju można też rozpatrywać jako trzy typy relacji: rzeczownik/rzeczownik, rzeczownik/przymiotnik i rzeczownik/czasownik (Górski i in. 1996: 129). 
3.2. Nazwa kategoria rodzaju w pracach polskich językoznawców pojawia się z reguły z określnikiem gramatyczna ${ }^{6}$. Zofia Zaron (2004: 10) zwraca uwagę, że gramatyczność rodzaju jest różnie rozumiana przez poszczególnych badaczy: jako problem fleksyjny, składniowy lub wieloaspektowo.

Tradycyjnie rozumiana kategoria rodzaju przysługuje wszystkim rzeczownikom (można ją określić i dla plurale tantum) i charakteryzuje cały leksem, wszystkie jego formy. Dzieli rzeczowniki na trzy klasy: męską, żeńską i nijaką, czyli jest klasyfikująca dla tej części mowy (klasyfikująca w opozycji do fleksyjna) ${ }^{7}$. Jest uznana za kategorię nie semantyczną (nie nominatywną), a gramatyczną, tekstową (por. np.: Laskowski 1999: 208). Dla rzeczowników oznaczających osoby, rodzaj rzeczownika męski, żeński jest najczęściej zgodny z płcią desygnatu. $\mathrm{W}$ aspekcie semantycznym zawierają w znaczeniu składnik < osoba płci męskiej, mężczyzna>, <osoba płci żeńskiej, kobieta>. Na przykład: rycerz, chłopiec, pilot - rzecz. r.m., kobieta, pani, malarka - rzecz. r.ż. Kategoria ta jest wtedy również - sekundarnie - nominatywna (dotyczy to także części nazw zwierząt domowych). Dużą rolę w przekazywaniu informacji o płci odgrywają formanty słowotwórcze (derywowanie nazw żeńskich od męskich): nauczyciel nauczycielka, woźny - woźna. Kategoria rodzaju dla rzeczownika jest kategorią syntaktycznie niezależną. Determinuje fleksyjną kategorię rodzaju części zdania pozostających z nim w związku syntaktycznym.

3.3. W obecnej chwili, po licznych procesach wyrównywania i różnicowania końcówek w paradygmacie rzeczownika, kategoria rodzaju: męski, żeński, nijaki jest kategorią sygnalizowaną tylko w liczbie pojedynczej. W liczbie mnogiej doszło do tak dalekich uproszczeń, że można mówić o braku dystynkcji rodzajowych. Natomiast w liczbie pojedynczej w większości przypadków końcówki rodzaju żeńskiego są wyraźnie różne od końcówek pozostałych rodzajów (w Mc. i W. rzeczowniki r.ż. z końcówką - $a \mathrm{w}$ M. mają końcówki -e, tak jak męskie twardotematowe i nijakie: kobiecie, płocie, oknie). W paradygmacie rzeczowników rodzaju męskiego i nijakiego doszło do licznych wyrównań, a zróżnicowanie pozostało dla M., B. i W.

3.4. Wielokrotnie dyskutowany był przez językoznawców problem morfologicznej charakterystyki klas rodzajowych. Obecnie za podstawę klasyfikacji przyjmuje się łączliwość rzeczownika z innymi częściami mowy: przymiotnika-

${ }^{6}$ Roman Laskowski klasyfikuje ją jako kategorię morfologiczną (Laskowski 1999: 207).

7 Nawet dla rzeczowników pluralia tantum (wbrew opiniom części językoznawców) można określić rodzaj (Zaron 2004: 39-42). 
mi, zaimkami, czasownikami i liczebnikami w M. i B. obu liczb (por. np. Saloni 1976, Laskowski 1999: 209, Wróbel 2001: 91). Według badaczy różne konteksty dowodzą istnienia różnych rodzajów ${ }^{8}$. Jednak obecność dystynkcji świadczy tylko o tym, że one istnieją, a nie o ich podstawach.

Roman Laskowski twierdzi, że klasy rodzajowe rzeczowników scharakteryzowane są w pierwszym rzędzie przez typowe dla każdej z nich synkretyzmy form fleksyjnych przypadków (Laskowski 1999: 212).

Zofia Zaron dyskutuje z tym poglądem. Uzasadnia, że niewystarczające jest kryterium samych synkretyzmów. Jej zdaniem dopiero zhierarchizowany układ końcówek obu liczb D., M. i synkretyzmy B. dzielą rzeczowniki na rozłączne klasy rodzajowe.

Jednak pozostając przy tradycyjnej klasyfikacji kategorii rodzaju na męski, żeński i nijaki, można przyjąć, że rodzaj dla większości rzeczowników jest przypisany tematowi i, jak twierdzi Wróbel, uczymy się go wraz z formą i znaczeniem (Wróbel 2001: 90). Za takim rozwiązaniem przemawia fakt, że pojawiają się problemy z doborem odpowiednich kontekstów, a nawet końcówek w przypadku rzeczowników, których rodzaj nie jest znany mówiącemu: ten rożen / to rożno, ta pomarańcza / ten pomarańcz.

3.5. Podstawową funkcją kategorii rodzaju jest wraz z kategorią przypadka i liczby sygnalizowanie związków syntaktycznych między rzeczownikiem - członem głównym - a pozostałymi składnikami grupy nominalnej. Udział kategorii rodzaju w sygnalizowaniu związku syntaktycznego między NP podmiotową a orzeczeniem dotyczy tylko części orzeczeń. Są to te, których budowa oparta jest na formie imiennej, np. orzeczenie w czasie przeszłym, w czasie przyszłym złożonym.

Kategoria rodzaju (męski, żeński i nijaki) we współczesnym języku polskim sygnalizuje zatem prymarnie wraz z kategorią przypadka związki syntaktyczne w NP występujących w liczbie pojedynczej, a największe zróżnicowanie jej wartości pojawia się w grupach mianownikowych i biernikowych. W pozostałych przypadkach występuje zróżnicowanie na rodzaj żeński i męsko-nijaki.

4.1. Dystynkcje żywotny/nieżywotny oraz osobowy/nieosobowy sygnalizowane w niektórych przypadkach rzeczowników rodzaju męskiego tradycyjnie

${ }^{8}$ Zob. także artykuł I. Bobrowskiego, w którym autor zwraca uwagę na to, że inne grupy rodzajowe rzeczownika otrzymujemy w kontekstach z czasownikiem, inne z przymiotnikiem (Bobrowski 2005). 
były traktowane w polskiej literaturze przedmiotu jako efekt działania jednego z „czynników” - semantycznego, wpływającego na repartycje końcówek. Obecnie przyjmuje się, że męskożywotność i męskoosobowość to równorzędne wartości kategorii rodzaju z takimi, jak np.: żeński i nijaki lub jej subkategorie (Górski i in. 1996: 127).

Inne podejście do zjawisk tego typu niż przyjęte wśród badaczy polskich proponował i uzasadnił, badając języki Australii, M. Silverstein (1976)9 . W swoim modelu interpretacji kategorii żywotności zbudował hierarchię dystynkcji semantycznych, która jest podstawą procesów gramatycznych w wielu językach ${ }^{10}$. Na szczycie modelu znajdują się opozycje wyróżniające bezpośrednich uczestników aktu komunikacji (wyrażane językowo za pomocą zaimków ja, ty), niżej opozycja [+/- imię własne], następnie [+/- osobowość], jeszcze niżej - [+/- osobowość i żywotność], najniżej - [+/- żywotność ${ }^{11}$. Dla każdego języka charakterystyczny jest właściwy mu poziom (poziom „cięcia”), powyżej którego rzeczowniki posiadające dane cechy semantyczne funkcjonuja $\mathrm{w}$ jego systemie jako „agentywne"12. Nazwy o cechach poniżej tego poziomu są „nieagentywne". Mają one właściwe sobie wykładniki formalne w strukturach nienacechowanych - rzeczowniki ,agentywne” są predestynowane do zajmowania miejsca I argumentu - podmiotu, „nieagentywne” miejsca II argumentu - dopełnienia bliższego. W przypadku nacechowania struktury, gdy rzeczownik agentywny zajmuje pozycję inną niż I argumentu (i zapewne występuje brak wyrazistych wykładników formalnych dla pozycji II argumentu) pojawiają się wykładniki formalne sygnalizujące to odstępstwo - np. w polszczyźnie B. rzeczowników rodzaju męskiego żywotnych i osobowych w 1.p. i osobowych w 1.m. jest równy nie M., lecz D. (w 1.p. końcówka - $a$, nie - $\varnothing$, w 1.m. -ów, -i/-y (rzecz. miękkotematowe), nie $-e,-i /-y$ (rzecz. twardotematowe), -owie. Teoria ta sprawdza się dla wielu języków na świecie ${ }^{13}$.

9 Przedstawiam za J. Mindak (1991: 116).

10 O podstawach semantycznych określonych pozycji składniowych pisał w licznych pracach Ch. J. Fillmore.

11 Model Silversteina został uzupełniony przez G. Lazarda (1984) o kryterium określoności.

12 W wielu językach europejskich „cięcie” znajduje się na poziomie [+/- żywotność] (por. Górski i in. 1996).

13 J. Mindak, badając języki słowiańskie, znalazła wiele argumentów, potwierdzających jej zasadność. 
Predestynowanie pewnych typów rzeczowników o określonych cechach semantycznych do zajmowania określonych pozycji w strukturach zdaniowych można wyjaśniać antropocentryczną perspektywą postrzegania rzeczywistości: „,...jesteśmy najbardziej zainteresowani istotami ludzkimi podobnymi do nas samych: ich działaniami, ich myślami, ich przeżyciami [...]. My - ludzie - zawsze zajmujemy we wszelkich opisach zdarzeń pozycję uprzywilejowaną. Jeśli w jakimś zdarzeniu bierze udział istota ludzka, to najczęściej ona właśnie będzie wymieniona na pierwszym miejscu, jako podmiot zdania.” (E. Tabakowska 2001: 23).

Zuzanna Topolińska na podstawie swoich badań frazy nominalnej w dialektach macedońskich zaproponowała antropocentryczną teorię przypadka. Uznała, że: „The primary semantic cases represent demands (implications) which the predicates makes on its arguments. I take the character of these relations to be a function of an anthropocentric theory of language. The inherent [+/-personal] character of the referent of the relevant NP is, therefore, of primary significance in the determination of case." (Topolińska 1996: 58) ${ }^{14}$.

Uczona modeluje ,,a projection of the 'a man-made` world”, w którym referentem pierwszego argumentu - subiektu jest prymarnie ludzka istota, referentem drugiego argumentu - obiektu nieożywiony obiekt materialny (w diatezie nienacechowanej) (Topolińska 1996: 60).

W dalszej części wywodu Topolińska analizuje kolejno poszczególne przypadki i przypisuje każdemu z nich zespół cech semantycznych ${ }^{15}$. Przykładowo mianownik interpretuje jako przypadek właściwy pierwszej ludzkiej istocie, biorącej udział w zdarzeniu narracyjnym i proponuje dla niego zespół cech semantycznych: [+human], [-generic], [-localistic], dla biernika - przypadka wyrażającego pierwszy materialny obiekt podaje: [-/+human], [-/+generic], [-/+localistic ${ }^{16}$. Dodaje, że jeżeli w tej pozycji pojawia się NP z cechami [+human] i/lub

14 Autorka uważa, że określone opozycje semantyczne zwiększają prawdopodobieństwo nadania relewantnej NP określonej formy przypadka. Najwyżej w hierarchii znajdują się zaimki 1 i 2 os. (czyli frazy nominalne, których referentami są protagoniści aktu mowy), następnie zaimki 3 os., zaimki osobowe w liczbie pojedynczej są wyżej niż w liczbie mnogiej, imiona własne są nad NP apelatywnymi, nazwy męskie nad żeńskimi, żywotne nad nieżywotnymi, policzalne nad substantivami. W korelacji z hierarchią określoności NP, których referent jest scharakteryzowany, [+identified] są wyżej od [-identyfied], [+specific] od [generic] (Topolińska 1996: 58).

15 Z. Topolińska wiąże z hierarchią żywotności także teorię przypadka, opartą na relacjach przestrzennych (Topolińska 1996: 58).

16 Autorka przedstawia mały zbiór możliwych modelowych sytuacji, które są podstawą struktur propozycjonalnych. Wyrażenie ,,pierwszy” jest związany z możliwością pojawie- 
[+animate], to powstaje dodatkowe nacechowanie, mające współcześnie w językach słowiańskich wykładnik - brak synkretyzmu B.=M., a w efekcie synkretyzm B.=D. W języku polskim jest to synkretyzm B. i D. obu liczb obecny tylko w rodzaju męskim ${ }^{17}$.

Podobne rezultaty rozważań można odnaleźć w artykule czworga autorów: R. I. Górskiego, J. Koniecznej-Twardzikowej, G. Minczewa, M. P. Mercader. Analizowali oni funkcjonowanie kategorii [+anim/-anim] w wybranych językach słowiańskich i romańskich. Według nich (o ile funkcjonuje w danym języku) jest powiązana z pozycją rzeczownika (a zatem i NP) w zdaniu i jest sygnalizowana dla NP pełniącej funkcję dopełnienia bliższego (Górski i in. 1996: 129).

4.2. Kategoria istotności poznawczej (żywotności) leży u podstaw hierarchicznego uporządkowania wyrażeń o określonych cechach semantycznych ze względu na ich wagę z jednej strony w schematach poznawczych, z drugiej w strukturach predykatowo-argumentowych i ich formalizacjach. Rzeczowniki o określonych cechach semantycznych powyżej poziomu „cięcia” funkcjonują w danym języku jako agentywne i predestynowane do pełnienia funkcji podmiotu - pierwszego argumentu (najwyższego rangą w strukturze predykatowo-argumentowej) w diatezie nienacechowanej. Te o cechach poniżej „cięcia” w pierwszym rzędzie zajmują pozycję drugiego argumentu - dopełnienia bliższego. Formalnymi wykładnikami tych funkcji jest opozycja M. : B. Obniżenie rangi agensa z wykonawcy czynności do obiektu podlegającego działaniu w wielu językach przejawia się podkreśleniem cechy [+osobowy] i/lub [+żywotny] przez wykładniki formalne ${ }^{18}$.

nia się drugiego obiektu materialnego i drugiej istoty ludzkiej w proponowanych schematach (Topolińska 1996: 59).

17 Kilka uwag natury diachronicznej może trochę przybliżyć problem. Sygnalizowanie cechy [+ żywotny] w rzeczowniku rodzaju męskiego przez synkretyzm B.=D. w liczbie pojedynczej w języku polskim pojawiało się już w prasłowiańszczyźnie. Odróżniało to te rzeczowniki od nieżywotnych rodzaju męskiego, które miały odziedziczony z prasłowiańszczyzny synkretyzm B.=M. w 1.p. W XVI w. synkretyzm dla żywotnych B.=D., dla nieżywotnych B.=M. w obu liczbach rzeczowników rodzaju męskiego był już normą (Wieczorkiewicz 1965: 75-81). W tym samym mniej więcej czasie (też jeszcze w XVII w.) dopełnienie bliższe przybiera coraz częściej formę biernika (Rospond 1971: 337). W XVII wieku w liczbie mnogiej dochodzi do dalszych zmian i klasa rzeczowników [+osobowy, +żywotny] dzieli się na dwie grupy. Osobowym pozostają wykładniki całej klasy - B.=D., żywotne nieosobowe przyjmują synkretyzm B.=M., charakterystyczny nie tylko dla nieżywotnych męskich, ale i dla liczby mnogiej pozostałych rzeczowników.

$18 \mathrm{~W}$ historii języka polskiego był moment (XVI w.), gdy w M. 1.m. rodzaju męskiego funkcjonowało odróżnienie żywotne: nieżywotne. Nieżywotne przybrały końcówkę B. Wią- 
W języku polskim wyrażenie formalnego obniżenia rangi agensa do pozycji obiektu pojawia się tylko w obrębie rodzaju męskiego. Sprzyjał temu zapewne odziedziczony z prasłowiańskiego synkretyzm B.=M. w 1.p. rzeczowników deklinacji męskiej, a w okresie późniejszym wytworzony też w liczbie mnogiej. W deklinacji żeńskiej w l.p. biernik jest różny od mianownika dla większości rzeczowników: kobieta/kobietę, pani/pania, ale noc/noc. Natomiast rzeczowniki rodzaju nijakiego - mają synkretyzm M.=B. w 1.p. (prawdopodobnie ze względu na typowe znaczenia - istoty niedorosłe, obiekty materialne, pojęcia abstrakcyjne). W liczbie mnogiej wszystkie rzeczowniki (mają M.=B. z wyjątkiem męskich osobowych) w bierniku obu liczb nie mają wykładnika formalnego zróżnicowania żywotne/nieżywotne, osobowe/nieosobowe (nie są ujmowane jako agensy w pozycji nieagentywnej):

Dziecko (M.) czyta. Chłopak widzi dziecko (B.).

Jagnię (M.) pije mleko. Chłopiec głaszcze jagnię (B.).

Okno (M.) jest w ścianie poludniowej. Otwórz okno (B.).

Kobiety (M.) szty droga. Chtopak widzi kobiety (B.).

Stoły (M.) stoja pod ściana. Chtopcy przesuwaja stoły (B.).

Stonie (M.) pija wodę. Chtopcy poja stonie (B.).

Semantyczna kategoria istotności poznawczej (żywotności) jest w języku polskim podstawą zróżnicowania rzeczowników rodzaju męskiego deklinacji I z końcówkami - $\varnothing /$ /-o (i rzeczowników o odmianie przymiotnikowej). Sygnalizowana jest przez nacechowanie nietypowej pozycji (dopełnienie bliższe) form agentywnych, które formalnie wyraża się synkretyzmem B.=D. w 1.p. rzeczowników o cechach [+osobowy] i [+żywotny], w 1.m. rzeczowników [+osobowy]:

Chtopiec oglada obrazki. Widzę chtopca. $\mathrm{B} .=\mathrm{D}$.

Stoń pije wodę. Widzę stonia. $\mathrm{B} .=\mathrm{D}$.

Chłopcy ogladaja obrazki. Widzę chłopców. B.=D., ale

Stót stoi pod ścianq. Widzę stót. B.=M.

Stonie pija wodę. Widzę stonie. $\mathrm{B} .=\mathrm{M}$.

Stoły stoja pod ścianq. Widzę stoły. B. $=\mathrm{M}$.

zało się ono z budowaniem w tym paradygmacie, na wzór l.m. innych deklinacji, ale też 1.p. tej - synkretyzmu B.=M. 
W przypadku rzeczowników rodzaju męskiego, odmieniających się według innych paradygmatów (jeżeli nie mają wykładników B.=D., np. mężczyzna w 1.p.), obniżenie rangi wyraża się przez związki syntaktyczne: widze sympatycznego -(B.=D.) mężczyznę -(B. różne od D.) $)^{19}$.

Prymarną funkcją semantycznej kategorii istotności poznawczej (żywotności) jest porządkowanie argumentów w strukturze zdania ze względu na cechę agentywne/nieagentywne. W języku polskim jej funkcjonowanie w rzeczowniku można obserwować w rodzaju męskim. W 1.p. rzeczowniki, które mają cechę [+żywotne] i/lub [+osobowe], w 1.m. cechę [+osobowe], są predestynowane do pełnienia funkcji I argumentu. W zdaniach rzeczowniki agentywne, które pojawiają się w pozycji II argumentu - dopełnienia bliższego, otrzymują nacechowanie B. różne od M. i w rezultacie B.=D. Kategoria ta wpływa też na pozostałe człony NP, będące w związku zgody z takim rzeczownikiem: Widzę sympatycznego, mitego chłopca (wszystkie wyrażenia $\mathrm{B} .=\mathrm{D}$.); Widzę duży stót (wszystkie wyrażenia B.=M. $)^{20}$.

W liczbie mnogiej w M. rzeczowników rodzaju męskiego kategoria istotności poznawczej przejmuje funkcje kategorii rodzaju w tworzeniu związków syntaktycznych w NP. W liczbie mnogiej przejmuje też sekundarnie funkcję kategorii rodzaju tych rzeczowników - bierze udział w tworzeniu związków syntaktycznych między głównym rzeczownikiem NP podmiotowej a orzeczeniem, które jest wyrażone formą czasownika posiadającą kategorię rodzaju. Rzeczowniki rodzaju męskiego z charakterystyką [+osobowe] w funkcji podmiotu determinują inną końcówkę fleksyjną czasownika niż pozostałe: Chłopcy siedzieli pod oknem. Psy siedziaty pod oknem. Dziewczęta siedziały pod oknem. Stoły staly pod oknem.

Ekspansję kategorii istotności poznawczej w liczbie mnogiej można próbować wyjaśniać zgodnie z linią wywodu Topolińskiej. Większa różnorodność wykładników występuje dla zjawisk uznawanych za ważne. Nazwy obiektów w liczbie pojedynczej stoją wyżej w hierarchii od wyrażeń w l.m. Dlatego też w 1.p. występują dwie kategorie (rodzaju i istotności), w liczbie mnogiej jedna - w funkcji obu.

19 Można zatem przyjąć, że nacechowanie dotyczy nie tylko samego rzeczownika, ale całej grupy, której jest on członem głównym.

${ }^{20}$ Obecnie można obserwować tendencję do szerzenia się synkretyzmu B.=D. dla nowych klas rzeczowników, np. nazw marek samochodów, typów żywności: Kupiłem białego fiata., Zjadtem dużego hamburgera. 
Dystynkcje kategorii istotności poznawczej występują w B. obu liczb rzeczowników rodzaju męskiego i dzielą je na trzy klasy: osobowe z końcówkami $-a$ w 1.p. i -ów, $-i /-y$ w l.m., żywotne nieosobowe z końcówkami $-a$ w 1.p. i $-y /-i$, $-e \mathrm{w}$ l.m. oraz nieżywotne z końcówkami $-\varnothing \mathrm{w}$ l.p. i $-y /-i,-e \mathrm{w}$ l.m.

5. W ostatnich dziesięcioleciach wśród językoznawców polskich ustaliło się stanowisko, że kategoria rodzaju gramatycznego rzeczownika przyjmuje pięć wartości: męskoosobowy, męskożywotny, męskorzeczowy, żeński i nijaki. W moich rozważaniach chciałam wykazać, że między kategorią rodzaju gramatycznego o wartościach: męski, żeński, nijaki a dystynkcją semantyczną żywotny/nieżywotny i osobowy/nieosobowy w obrębie rodzaju męskiego występują znaczące różnice. Opozycje żywotny/nieżywotny i osobowy/nieosobowy są traktowane w literaturze przedmiotu jako dystynkcje semantycznej kategorii żywotności. W związku z dokonanymi ostatnio uzupełnieniami tej kategorii proponuję przyjąć dla niej nazwę kategorii istotności poznawczej. Określenia obiektów, które są dla komunikujących się osób ważniejsze poznawczo, np.: nadawca, odbiorca, działający ludzie, zwierzęta, mają bardziej uprzywilejowaną pozycję i zróżnicowane wykładniki w strukturze gramatycznej języka.

Oto podstawowe różnice między gramatyczną kategorią rodzaju i semantyczną kategorią istotności poznawczej:

1. a) Prymarną funkcją kategorii rodzaju jest sygnalizowanie wraz z kategorią przypadka i liczby związków syntaktycznych w grupie nominalnej między rzeczownikiem - jej członem głównym a jej pozostałymi składnikami.

b) Prymarną funkcją semantycznej kategorii istotności poznawczej jest wraz z kategorią przypadka sygnalizowanie hierarchii argumentów w zdaniu, przede wszystkim pod względem opozycji agentywne/nieagentywne.

2. a) Współcześnie kategoria rodzaju dla przeważającej części rzeczowników jest kategorią tekstową, tylko dla nazw osób i niektórych zwierząt można przypisać jej odniesienie do rzeczywistości pozajęzykowej - jest nominatywna.

b) Kategoria istotności poznawczej jest kategorią semantyczną.

3. a) Wartość kategorii rodzaju dla większości rzeczowników jest przypisana do tematu.

b) Kategoria istotności poznawczej oparta na opozycji agentywny/nieagentywny w języku polskim wiąże się w liczbie pojedynczej rzeczowników rodzaju męskiego z cechą semantyczną [+/-żywotny], w liczbie mnogiej 
[+/-osobowy]. Rzeczowniki ujmowane agentywnie są predestynowane do zajmowania pozycji I argumentu w wyrażeniu zdaniowym. W przypadku ich pojawienia się w pozycji II argumentu zostają nacechowane zmianą synkretyzmu właściwego I deklinacji $-\mathrm{B} .=\mathrm{M}$., na B. $=\mathrm{D}$.

\section{Bibliografia}

Bobrowski I., 2005, Rodzaj gramatyczny rzeczownika a jego liczba, Język Polski $L X X X V$, s. 83-89.

Górski R. I., Konieczna-Twardzikowa J., Minczew G., Mercader M. P., 1996, Rodzaj żywotny/osobowy: dzieli czy łączy języki? Analiza kontrastywna wybranych języków słowiańskich i romańskich na przykładzie rzeczownika, Biuletyn PTJ LII, s. $127-134$.

KucaŁa M., 1971, Zanikanie kategorii żywotności-nieżywotności w jednej z gwar polskich, Studia z Filologii Polskiej i Stowiańskiej 10, s. 43-57.

KuCAŁa M., 1976, O rodzaju gramatycznym w języku polskim, w: R. Laskowski (red.), Kategorie gramatyczne grup imiennych w jezzku polskim. Materialy konferencji w Zawoi 13-15 XII 1974, Wrocław: Wydawnictwo Naukowe PAN im. Ossolińskich, s. $79-87$.

LASKOWSKI R., 1984, wersja poprawiona 1999, Kategorie morfologiczne języka polskiego, w: R. Grzegorczykowa, R. Laskowski, H. Wróbel (red.), Gramatyka wspótczesnego języka polskiego. Morfologia, Warszawa: Wydawnictwo Naukowe PWN.

LazArd G., 1984, Actance Variations and Categories of the Object, w: F. Plank (red.), Objects, Towards a Theory of Grammatical Relations, London: Academic Press, s. 269-292.

MańCZaK W., 1956, Ile rodzajów jest w polskim, Język Polski XXXVI, s. 116-121.

MindaK J., 1990, Jezykowa kategoria żywotności w polszczyźnie i słowiańszczyźnie na tle innych języków świata. Próba ujęcia typologicznego, Wrocław: Seria Prace Slawistyczne PAN.

MindAK J., 1991, O smrekach, korzeniach i zębach - Ewolucja gramatycznej kategorii żywotności w języku polskim, w: M. Grochowski (red.), Problemy opisu gramatycznego języków stowiańskich, Warszawa: Wydawnictwo Naukowe PAN, s. 115-118.

Rospond S., 1971, Gramatyka historyczna języka polskiego, Warszawa: Wydawnictwo Naukowe PAN.

SAloni Z., 1976, Kategoria rodzaju we współczesnym języku polskim, w: R. Laskowski (red.), Kategorie gramatyczne grup imiennych we wspótczesnym języku polskim. Materiaty konferencji w Zawoi 13-15 XII 1974, Wrocław: Wydawnictwo Naukowe PAN im. Ossolińskich, s. 41-76. 
Silverstein M., 1976, Hierarchy of features and ergativity, w: R. M. W. Dixon (red.), Grammatical Categories in Australian Languages, Canberra: Australian National University, s. 112-171.

TAваKOwSKa E. (red.), 2001, Kognitywne podstawy języka i językoznawstwa, Kraków: Universitas.

Topolińska Z., 1996, Anthropocentric Language Theory as Organizing Principle of the Slavic Case System, Biuletyn PTJ LII, s. 57-72.

WieCZORKIEWICZ B., SinielNikoff R., 1965, Elementy gramatyki historycznej języka polskiego, Warszawa: PZWS.

WróBel H., 2001, Gramatyka języka polskiego, Kraków: Spółdzielnia Wydawnicza „OD NOWA".

ZARON Z., 2004, Aspekty funkcjonalne polskiej kategorii rodzaju. Charakterystyka fleksyjna, Warszawa-Puńsk: Wydawnictwo „Auśra”.

\section{Grammatical Gender and the Semantic Category of Cognitive Significance}

\section{( s u m m a r y)}

In contemporary Polish grammatical gender has 5 realizations: masculine personal, masculine animate, masculine nonanimate, feminine, neuter.

In this article the author proves that the distinctions observed in language structure indicate two different categories: gender and cognitive significance [+/-agentive]. The distinctions within the category of gender (masculine, feminine and neuter) appear only in the singular. It's main function (together with the category of case and number) is the creation of appropriate syntactic relations in NP.

The primary function of the semantic category of cognitive significance is ordering the hierarchy of arguments in sentences on the ground of the opposition $+/$ - agentive (+/animate in the singular, +/-personal in the plural). 